пізнавальної активності він перебуває і 3 яким рівнем самостійності здійснюється проектувальна діяльність.

\title{
Література
}

1. Дворецкий С. Формирование проектной культуры / С. Дворецкий // Высшее образование в России, 2003. - №4. - 193 с.

2. Матюшкин А. М. Теоретические исследования. Психологическая структура, динамика и развитие познавательной активности / А. М. Матюшкин. // Вопросы психологии/ [электронный ресурс] адрес http//www.voppsy.ru/issues/1982/824/824005.htm C. 5-17.

3. Новые педагогические и информационные технологии в системе образования: [учебн. пособие для студентов пед. вузов и системы повышения квалификации педагогических кадров] / Е. С.Полат и др. ; под ред Е. Полат. - М.: Издательский центр «Академия», 1999. - 123 с.

4. Пахомова Н. Ю. Учебный проект: его возможности / Н.Ю.Пахомова // Учитель. 2000. - №4. - С. 15-35.

5. Советский энциклопедический словарь. - М. : Советская энциклопедия, 1989. - 1630 с.

6. Тарасова И. П. Метод проектов в образовательном учреждении / И. П.Тарасова // Приложение к журналу «Профессиональное образование», 2004. - №12. - 110 с.

Стаття надійшла до редакції 23.05.2012 p.

\section{КОМПОЗИЦІЯ УКРАЇНСЬКОГО НАРОДНОГО ОДЯГУ ЯК ДЖЕРЕЛО ВИВЧЕННЯ ОСНОВ ЕТНОДИЗАЙНУ} \author{
етнодизайну. \\ Кучер С. Л. Композиція украӥнського народного одягу як джерело вивчення основ \\ У статті розкрито питання ознайомлення майбутніх учителів технології з особливими
} рисами національного етнодизайну. Одну із сторін етнодизайну, що пов'язана із творенням одягу, пропонується вивчати у три етапи: 1) ознайомлення з композицією національного костюму; 2) виготовлення традиційного вбрання на основі багатовікової технології; 3) трансформачія ідей украӥнського народного одягу в дизайні сучасного вбрання та аксесуарів.

Ключові слова: підготовка учителів технологій, композииія одягу, традиціийий украӥнський костюм, етнодизайн.

Кучер С. Л. Композиция украинской народной одежды как источник изучения основ этнодизайна.

Статья раскрывает вопросы ознакомления будущих учителей технологии с особенными чертами национального етнодизайна. Одну из сторон етнодизайна, связанную с созданием одежды, предлагается изучать в три этапа: 1) ознакомление с композицией национального костюма; 2) изготовление традищионной одежды на основе многовековой технологии; 3) трансформация идей украинской народной одежды в дизайне современного костюма и аксессуаров.

Ключевые слова: подготовка учителей технологий, композиция одежды, традиционный украинский костюм, етнодизайн.

Kucher S. The composition of the Ukrainian national clothes as a source of learning the basics etnodizayna.

The article reveals problems familiarize future teachers with the technology of special features of national design. One of the parties of design based on ethnic associated with the creation of clothing, 
it is proposed to studyin three phases: 1) an introduction to the composition of the national costume, and 2) the manufacture of traditional clothing, based on a centuries-old technology, and 3) the transformation of ideas of Ukrainian folkdressin the design of modern costume and accessories.

Key words: training teachers of technology, composition of clothes, traditional Ukrainian costume, design based on ethno.

Постановка проблеми. Світова історія сповнена прикладів, коли люди, натхнені національною ідеєю, давали високий розвиток державі. Національна ідея українців, напевне, ще не досягла тісї висоти, щоб надати поштовху для подолання державних проблем. Хоча українцям є чим пишатися і що вивчати. На нашу думку, найбільш яскравим і барвистим грунтом для зрощення національної гордості серед молоді є українська художня культура.

Українське народне мистецтво високо ціниться серед представників Європи та інших країн (не лише мистецтвознавців). І одним із найцікавіших i популярніших все ж таки є традиційний одяг, який приваблює не лише яскравим оздобленням, але універсальністю, зручністю та комфортністю у використанні. Тут на першому місці, звісно, народна вишита сорочка вишиванка. Чим більше іноземних громадян відвідують Україну, тим більше у світі стає прихильників і шанувальників українського національного мистецтва, усіх виявів матеріальної етнічної культури. Проте власне українська молодь досить далека від захоплення національним одягом i дедалі рідше зустрінеш дівчину чи хлопця у вишиванці.

Вишиванка - це візитна картка українського народу. В синтезі з іншими видами декоративно-ужиткового мистецтва вона $\epsilon$ часткою української народної традиції, національний культурний образ якої є унікальним явищем світової цивілізації. 3-поміж усіх типів українського національного одягу, до яких відносять натільний (власне сорочка), поясний (чоловічий - штани; жіночий - запаски, обгортки, плахти, спідниці, фартухи), нагрудний (керсетки, камізельки, кептарі, лейбики, кофти, юпки тощо) із сорочкою пов'язано найбільше обрядів, повір'їв, традицій, iï виготовленню i оздобленню надавалося найбільше магічне і символічне значення.

Нині студенти технолого-педагогічного факультету цікавляться модою, прагнуть одягатися красиво i виявляти індивідуальність, виготовляючи одяг власноруч. Проте, не маючи від природи хисту стиліста, не так просто досягти гармонії і створити щось дійсно достойне та оригінальне. А для майбутнього учителя трудового навчання досить важливо орієнтуватися у стилях і течіях сучасної моди та дизайну, знати їх витоки.

Особливість підготовки майбутнього вчителя технологій полягає у тому, що поряд з опануванням основ психолого-педагогічних дисциплін студенти повинні досконало оволодіти різноманітними спеціальними технологіями, особливо художньо-практичного спрямування. Знання історії українського костюму необхідні для професійної освіти не лише художників, істориків, мистецтвознавців, етнографів, модельєрів, а також мають неперевершене значення для виховання підростаючого покоління. 
Мета статті - розкрити можливості глибокого опанування основ українського етнодизайну на основі вивчення студентами композиції українського національного костюму.

Аналіз останніх досліджень і публікацій. Дослідження мистецтвознавців та етнографів, таких як Т. Кара-Васильєва, Е. Литвинець, О. Воропай, В. Скуратівський, містять цінні матеріали щодо історичного розвитку українського національного вбрання. Питання етнодизайну торкаються у своїх наукових роботах вітчизняні дослідники дизайну: Б. Тимків, В. Даниленко, Ю. Легенький, С. Шумега.

Цікавими для нас стали дослідження науковців та практиків за останні 20 років: Є. Антонович, Р. Захарчук-Чугай, М. Станкевич (сутність декоративно-прикладного мистецтва); Я. Запаско (детальне термінологічне пояснення особливостей національного декоративно-ужиткового мистецтва); А. Пономарьов, Л. Артюх, Т. Косміна (українська минувшина в ілюстрованому етнографічному довіднику) та інші.

Виклад основного матеріалу. Нині у підготовці вчителя технології вивчення костюмного комплексу видається одним із найважливіших напрямів у дослідженні рідної матеріальної культури, світогляду, символіки, традицій декорування одягу. Окрім того, традиційний костюм $є$ виразником релігійних уявлень народу про оточуючий світ, етнічної самосвідомості та був показником категорії «свій-чужий».

Знання історичних і культурних надбань предків, збирання українських вишиванок необхідні для естетичного, духовно-морального, гуманістичного виховання молоді, для піднесення національної гідності та свідомості. Заглиблене ознайомлення 3 костюмом та його семантикою може стати потужним стимулятором для творчості, оскільки дає можливість усвідомити всю красу, глибину, багатовікову логіку та не випадковість всіх елементів костюмного комплексу. Основні елементи українського народного одягу мають давнослов'янське походження. Це домоткані тунікоподібні сорочки, поясний одяг у вигляді прямокутної орнаментованої смуги тканини, вузькі полотняні чоловічі порти, рушникоподібне жіноче головне вбрання, плетені й ткані пояси та інше. Сорочка - один з найдавніших елементів одягу.

Вишиванка - символ здоров'я, краси, щасливої долі, родової пам'яті, національної гордості, порядності, чесності, любові, святковості, оберіг. Із цього погляду сорочка має вивчатись в різних аспектах - культурологічному, філософському, соціологічному, педагогічному, етнографічному, мистецтвознавчому тощо. Ще одна галузь людської діяльності - дизайн теж досліджує і бере за витоки саме народні види декоративно-прикладного мистецтва, що $€$ взірцем реалізації головного принципу дизайну оптимального сполучення краси і зручності.

Поняття «етнодизайн» з'явилося не так давно, і не всі науковці визнають його право на існування. Частіше можна зустріти термін «етнофутуризм», «етностиль», який в дизайні характеризується художньоестетичними рисами, що коріняться у народному декоративно-прикладному 
мистецтві. Будь-яка сформована нація має більше або менше розвинений етностиль.

Український етностиль дуже виразний i колоритний, адже увібрав багатовікову історію нашої землі. Витоки українського етнодизайну знаходять у трипільській землеробській культурі, що налічує тисячі років і має багато спільного із устроєм життя, розміщенням житла та суто українським декором.

Типові риси українського національного етностилю - у сучасній термінології це «бренди»: вишивка національних орнаментів, ікона на покуті в рушнику, дідух, розмаїта кераміка, дерев’яні різьблені витвори, традиційні прикраси коралі й дукачі, петриківський розпис та інше. В сучасному дизайні вони використовуються як акценти, стильний декор.

Розглядаючи аспекти поняття «етнодизайн» С. Борисова висловлює думку, що «етнофутуризм надає можливості для трансформації видів декоративно-ужиткового мистецтва, а іноді змінює навіть ціннісне ставлення до окремих явищ матеріальної і духовної культури. Прикладом матеріальної трансформації може бути зміна традиційної технології виготовлення виробу на новітню. Прикладом духовної трансформації $є$ той факт, що нині орнамент набуває самостійної цінності, а за умов творення нових міфів окремі елементи не тільки набувають нового значення, а і створюють нове поле етнічної орнаменталістики в полікультурному середовищі» [2]. Особливо широко нині виявляється етніка у рекламі деяких товарів та декорі упаковки.

Відомий дослідник українського мистецтва Б. Тимків наголошує, що «об'єктом етнодизайну є поєднання сучасних художніх технологій i етнокультурних традицій регіону». Етнодизайн має виявлення в різних сферах дизайну, в тому числі й у створенні одягу. Основними принципами організації занять з етнодизайну науковець вважає:

a) передання студентами знань про першоджерела вітчизняної дизайнерської думки, витоки, художні і виконавські традиції народного мистецтва;

б) розвиток конструктивного мислення, формування уявлень про декоративність, які передбачають гармонійне i цілісне розв'язання художнього виробу;

в) забезпечення проектної та художньо-виконавської культури, яка включає засвоєння певних принципів моделювання одягу і конструктивного розв'язання предметно-просторового середовища, а також художньотехнологічних прийомів виготовлення та декорування виробів [6, с.173-174].

Ми переконані, що для повноцінного творчого «занурення» у особливості національного етностилю необхідно доповнити заняття 3 етнодизайну в одязі створенням сучасних креативних виробів.

Підготовка вчителя технології за спеціальністю «конструювання та моделювання одягу» на технолого-педагогічному факультеті Криворізького педагогічного інституту включає вивчення дисциплін «Спеціальний малюнок», «Основи композиції одягу», «Елементи декоративно-прикладного 
мистецтва», «Дизайн одягу». У перебігу вивчення вищеназваних навчальних курсів студенти мають змогу різнобічно ознайомитися із особливостями українського національного вбрання.

Першим етапом ознайомлення з національним етнодизайном в одязі $€$ вивчення композиції національного костюму. Вивчення особливостей крою, декоративного оздоблення, семантики української народної сорочки відбувається на заняттях 3 курсу «Основи композиції одягу» (другий курс) в модулі «Український народний одяг». Основні питання, що піднімаються в лекційних заняттях: народний одяг як ансамбль; вікова, статева, соціальна градація одягу; сорочка як елемент українського народного костюму; типи сорочок; композиція сорочки; регіональні відмінності в конструкції та оздобленні жіночої сорочки.

Для студентів технолого-педагогічного факультету по-новому звучить термін «композиція» стосовно одягу, оскільки їх художня освіта обмежується уроками малювання в школі. Якщо композиція в образотворчому мистецтві зазвичай характеризується як певний порядок розташування елементів зображення, які сприймаються цілісно завдяки певній ідеї (концепції), то в одязі це поняття вимагає уточнення. Наприклад, композиція сорочки визначається як чітко продумана й логічна конструктивно-декоративна система взаємозв'язку площин вишивки, поєднання ажурних швів і вільних частин білого тла, що підкреслює декоративність вишивки. I хоча орнаментувалися поверхні сорочки за визначеним принципом (рукава, поділ, пазуха, комір), прикладів композиційного розв'язання подібних виробів існує безліч.

У найдавніші часи сорочка мала певну магічну функцію. Василь Скуратівський стверджує, що «вишивка на подолі сорочок та блуз, рукавах, комірі чи пазусі - не просто прикраса, а насамперед охоронне коло, яке мало забезпечити людину від злої сили» [5, с.82]. У процесі історичного та культурного розвитку в Україні в кожній місцевості утворилися характерні орнаментальні мотиви й композиції, колірна гама, специфічні техніки виконання. Дбайливо передавалися вони $з$ покоління в покоління, майстри відшліфовували кращі досягнення своїх попередників, розвиваючи й удосконалюючи їх. Характер вишивки, вибір тих чи тих орнаментальних мотивів, колірне рішення залежало від призначення одягу, соціальних i вікових чинників. Приміром, сорочки на щодень вишивалися скромно й просто, святкові - ретельніше, передовсім весільні сорочки.

Увесь процес, пов'язаний з виготовленням сорочок, їх одяганням i носінням, супроводжувався цілісною системою чітко визначених дійств i обрядів, окремі елементи яких дійшли і до наших днів. Народна майстриня Мирослава Кот говорить так: «Вишита сорочка - це давня традиція, повна глибокого змісту. Це символ краси і чистоти, майстерності і естетичного смаку, святковості. Здавна сорочці приписувалася чарівна сила, 3 нею пов'язана ціла низка повір'їв, звичаїв, обрядів. Сорочка часто розглядається як двійник людини, що іiі носить. Сорочка найближча до тіла і іï шили, вишивали, носили так, щоб не порушувати давніх звичаїв» [4, с.12]. 
Чітко визначалися дні виготовлення сорочок. Не годилося краяти полотно й шити його в суботу. Найкращою дниною для шиття сорочки вважався четвер. За повір'ям, такий виріб довго носитиметься, а його господар, якщо сорочки нікому не позичати, доживе до глибокої старості.

Процес вишивання, як правило, супроводжувався співами. Вважалося, що вишиванка, виготовлена під мелодійний супровід, принесе іiї власникові довголіття, щасливу долю й удачливе подружнє життя. Але найбільше акцентувалася увага на оздобленні нагрудного розшиву. Найпишніші i найбагатші узори зосереджені на грудях чоловічих сорочок. Це не лише естетичний момент - хоч і він має неабияке значення, - а насамперед міфологічна функція. Давні узори мали оберігати людину «від лихого ока» та чорних і злих духів. Цій меті слугували й мережки на кінцях рукавів та горловині. Кожен узор, нанесений на полотні, сприймався насамперед як охоронний знак, а сама мережка - як замкнуте коло, через яке не могла проникнути зла сила.

В. Скуратівський на основі багаторічних етнографічних пошуків зробив висновок, що «святкові, як, до речі, й повсякденні сорочки пишно оздоблювалися мережками. На дівочому, як і жіночому вбранні, прикінцеві береги - шия, пазуха, рукави і поділ - обов'язково обшивалися мережками чи вишивалися. Такий ансамбль дозволяв юнці чи молодиці за допомогою охоронних знаків, себто мережок з рослинними чи геометричними узорами, убезпечитись од злих духів та недобрих очей» $[5$, с.86].

Пацьорки, за допомогою яких стягується комірець, сукали 3 кольорових вовняних ниток, на яких з обох кінців прилаштовували китички. Вони також виконували важливу оберегову функцію (це рівнозначно стосується як чоловічих сорочок, так і жіночих блуз).

Другий eman ознайомлення майбутніх учителів технології 3 етнодизайном - виготовлення традиційного вбрання на основі багатовікової технології - відбувається на третьому курсі, при вивченні «Елементів декоративно-прикладного мистецтва». На заняттях 3 курсу студенти отримують практичні уміння 3 виготовлення та оздобленню народної сорочки, плахти, запаски та плечового одягу. Всі названі вироби виготовляються у зменшеному масштабі, це може бути одяг для вузлової ляльки-сувеніра або дитячий. На початку роботи з виготовлення моделей традиційного українського одягу студенти проводять підготовчу роботу, яка передбачає: збирання ілюстрацій народного вбрання різних регіонів України; опис обраного для виготовлення костюму з позиції його статевої та вікової градації; добір відповідних матеріалів для виготовлення (мають бути натуральні тканини та нитки - льон, шерсть, бавовна).

На даному етапі діяльності 3 виготовлення народного костюму студенти розробляють конструкцію для кожного предмету одягу. На практичних заняттях декоративно-прикладним мистецтвом студенти обирають один із традиційних способів крою народної сорочки i конструюють виріб у відповідності до заданих розмірів. Важливим у цій 
роботі $є$ чітке дотримання народних традицій не тільки у композиційній побудові та семантиці костюму, а й у технології його виготовлення.

На заняттях по ознайомленню з особливостями національного одягу студенти 3 подивом дізнаються про те, що найдавнішою $з$ технік вишивки в українському одязі вважається не «хрестик», а такі лічильні техніки, як гладь та мережка, і що вишивальних швів української народної вишивки існує більше ста видів. Оскільки технік оздоблення одягу досить багато, студенти тренуються виконувати традиційні ручні шви і візерунки спочатку на невеликих виробах, щоб згодом використовувати ці уміння у творчій роботі.

Зміст роботи на третьому етапі ознайомлення майбутніх учителів технології з етнодизайном у моделюванні одягу полягає у трансформації ідей українського народного одягу в дизайні сучасного вбрання та аксесуарів. Така робота організується на заняттях 3 «Дизайну одягу».

Костюмні комплекси різних народів становлять собою одне 3 основних джерел натхнення для експериментів у дизайні одягу по всьому світі. Українська сорочка (та й взагалі народний костюм) нині привертає увагу видатних художників-модельєрів, і не лише українських, як унікальний історичний досвід, потрібний для сучасної практики та для майбутнього. Творчість успішних сучасних українських художників-дизайнерів одягу $є$ яскравою ілюстрацією. О. Караванска, Р. Богуцька, Л. Пустовіт, І. Каравай, В. Гресь регулярно повертаються до вивчення і відтворення елементів народного вбрання, доводячи, що у вітчизняних традиціях, історії та культурі $є$ вдосталь того, що вигідно вирізнятиме нашу моду в світі.

Спираючись на доробок сучасних педагогів-художників, можемо стверджувати, що сучасний костюм 3 елементами народного має великі перспективи. При цьому в творчому опрацюванні студентами ці елементи не передбачають сліпого копіювання, а мають стати основою зваженої грамотної інтерпретації [6, с.173]. Сутність дизайнерського пошуку - не повторювати джерело, а зберігати його вплив, щоб модель інтерпретувала традиційні образи, розкриваючи їх під іншим кутом. Саме тому при вивченні етнічного джерела важливо зібрати найбільшу кількість культурних асоціацій, щоб дослідження і натхнення автора трансформувалися в дизайн.

Висновки. Дослідивши тему можливостей вивчення майбутніми учителями технології основ етнодизайну, ми дійшли висновку, що в реалізації поставлених завдань необхідно дотримуватися послідовності і наступності у виборі змісту навчального матеріалу. Це означає, що для глибокого розуміння національного стилю в мистецтві студенти мають неодноразово зустрітися 3 певними темами, але вивчати їх на якісно новому рівні, з поступовим переходом від теоретичного до практичного і творчого вивчення. 3-поміж інших видів національного декоративно-прикладного мистецтва, саме костюмний комплекс українців може стати предметом такого змістовного багаторівневого вивчення, що пов'язано 3 його різноманітністю та довголітньою історією. 


\section{Література}

1. Антонович Є.А. Декоративно-прикладне мистецтво / Є.А. Антонович, P.В. Захарчук-Чугай, М.Є. Станкевич. - Львів : Світ, 1992. - 272 с.

2. Борисова С. Етнодизайн як явище сучасної культури. [Електронний ресурс]. Режим доступу: http://www.nbuv.gov.ua>Portal/Soc_Gum/Gnvp/ 2011_54/4.pdf

3. Даниленко В.Я. Основи дизайну: [навч. посіб. ]/В.Я.Даниленко.-К.: IЗМН, 1996.- 92 с.

4. Вишивка Дрогобиччини. Традиції і сучасність / М.П. Кот /Альбом. - Львів: Інститут народознавства НАН України, 1999. - 107 с.

5. Скуратівський В.Т. Покуть : народознавчі матеріали /В.Т. Скуратівський/. - К. : Фірма Довіра, 1992. - 230 с.

6. Тимків Б.М. Роль етнодизайну в підготовці художників декоративно-прикладного мистецтва. - Наукові записки: Серія Педагогіка. - 2011. - №3. - С.171-176.

7. Українська минувшина: Ілюстрований етнографічний довідник. - 2-е вид. /А.П. Пономарьов, Л.Ф. Артюх, Т.В. Косміна та ін./ - К.: Либідь, 1994. - 256 с.

Стаття надійшла до редакції 23.05.2012 p.

УДК 378.78(07):004

Л. I. Варнавська,

кандидат пед. наук, ст. викладач, Криворізький педагогічний інститут ДВНЗ «Криворізький національний університет»

\section{КОМП'ЮТЕРНІ ТЕХНОЛОГІї: МОЖЛИВОСТІ ВИКОРИСТАННЯ В МУЗИЧНІЙ ОСВІТІ}

Варнавська Л. І. Комп 'ютерні технології: можливості використання в музичній освіті.

Актуальність матеріалу, викладеного в статті, зумовлена стрімким розвитком комп'ютерних технологій, поширенням їх застосування в науці, освіті, повсякденному житті. Питання необхідності використання засобів комп ютерних технологій у сучасному освітньому просторі, зокрема, в музичній освіті, перебувають у полі посиленої уваги багатьох педагогівмузикантів, потребують наукового підходу до иієї проблеми. Деякі засади використання засобів комп'ютерних технологій на уроках музики, розглянуті у статті, визначають спрямування їх застосування в музичній освіті.

Ключові слова: комп 'ютерні технології, навчально-виховний прочес, музична освіта.

Варнавская Л. И. Компьютерные технологии: возможности использования 6 музыкальном образовании.

Актуальность материала, изложенного в статье, обусловлена быстрым развитием компьютерных технологий, распространением их использованием в науке, образовании, повседневной жизни. Вопросы необходимости использования компьютерных технологий в современном образовательном пространстве, а именно, в музыкальном образовании тревожат многих педагогов-музыкантов, требуют научного подхода к этой проблеме. Некоторые вопросы использования средств компьютерных технологий на уроках музыки, рассмотренные в статье, определяют направление их использования в музыкальном образовании.

Ключевые слова: компьютерные технологии, учебно-воспитательный процесс, музыкальное образование.

Varnavskaya L. Computer technology: potential use for music education.

The actuality of the material, given in the paper, is caused by the rapid development of computer technologies, their widespread application in science, education and everyday life. The necessities of using the means of computer technologies in the modern informative world, in musical education to be exact, attract the attention of music teachers and require the scientific approach to this problem. Some of the computer technologies applications in music classes, viewed in the paper, define their wide potential in the process of teaching music.

Key words: computer technologies, educational process, musical education. 